\title{
Problematising the Relationship between Teenage Boys and Parent Abuse: Constructions of Masculinity and Violence
}

\author{
Helen Baker \\ Department of Law and Criminology, Edge Hill University \\ E-mail: Helen.Baker@edgehill.ac.uk
}

Although research into parent abuse is scant in the context of the UK, there is now a burgeoning of interest into how this form of family violence fits into the historically well-defined arena of domestic violence research. This article investigates one aspect of the phenomena of parent abuse; that is, how teenage boys, who are often perceived as perpetrators of such violence due to problematic 'cycle of violence' or 'intergenerational transmission of violence' theories, are constructed in relation to it. These now widely discredited theories, which correlate being a man with being violent, are problematic, but may re-emerge as a possible explanation for parent abuse. This article questions these theories in the context of both domestic violence and parent abuse by demonstrating how they are based upon a culturally constructed notion of masculinity.

Keywords: Cycle of violence, parent abuse, masculinity, teenage boys, violence.

\section{Introduction}

Historically, the impact of domestic violence upon children and young people has been comparatively neglected in relation to violence against adult women (Mullender and Morley 1994: 2). This is because children as a group have been assumed to be passive, secondary victims of the violence which occurs between adults. However, as Kelly states: 'children are individuals who act and make choices, and who develop, in contexts of necessity, coping and survival strategies' (1994: 44). It is also now well established that children can be and are profoundly affected by domestic violence in both the short and long term, emotionally, psychologically and physically, whether they directly or indirectly experience it (Mullender et al., 2002: 207).

Domestic violence, however, affects children and young people differently as its effects are influenced by the age, race, class, gender, disability and sexuality of the child, in addition to their individual resilience (Hester et al., 2007: 63). Significantly, for some children and young people these effects may include demonstrating aggression and/or anger to their mothers and/or others, including other adults and siblings (McGee, 2000: 48; Hester et al., 2007: 64).

Domestic violence and its impact upon adults and children is, arguably, relatively well understood from both the victims' and perpetrators' perspectives whether they be children, adults, male or female (Hearn, 1998; Kelly, 1988; Dobash and Dobash, 1992; Mullender et al., 2002). There is, however, significantly less known about the phenomenon of child towards adult violence, or so-called 'parent abuse' (terms which are currently contested, see for example Cottrell, 2001; Nixon et al., 2010). Recent international studies 
suggest that it has a 5-18 per cent incidence rate (cf. Ulman and Strauss, 2000; Cottrell, 2001; Gallagher, 2004a, 2004b; Crichton-Hill et al., 2006).

Moreover, studies suggest that there is a significant correlation between witnessing and experiencing domestic violence by children and young people and the onset of behavioural problems such as aggression towards their adult carers, who are usually their mothers, as distinct from 'usual' growing pains (Crichton-Hill et al., 2006; Hester et al., 2007: 72-4). As this article explores, such behaviour has historically been understood in relation to adult domestic violence as a result of problematic 'cycle of violence' theories by which children replicate the behaviour of the same sex parent/carer as either a violent (male) perpetrator or as a (female) victim. There is, however, a clear danger of the reappearance of such theories in explaining why child to parent violence occurs, in the context of a current dearth of research in the United Kingdom on this issue. ${ }^{1}$

Child to parent violence also raises significant conceptual difficulties for domestic violence research because of the dominant feminist paradigm of domestic violence as being an adult male perpetrator committing abuse against a female victim. Although there are, according to Hunter et al., striking similarities between male violence against women in intimate partnerships and parent abuse, they state that there are a more complex set of dynamics at issue in relation to parent abuse and that 'the two forms of violence are not synonymous.' (2010: 266-7).

This article therefore suggests that the phenomena of child to parent violence needs to be investigated carefully and methodically, as complex explanations are needed to provide a comprehensive understanding of the development of violent behaviour in some but not all young adults (Cottrell, 2004; Crichton-Hill et al., 2006). It focuses specifically upon teenage boys in relation to parent abuse due to the way that they are often constructed as 'potentially violent men' simply because they are of the male gender (Baker, 2009). In so doing, it will explore and problematise how masculinity is socially constructed in relation to violence.

This article begins by examining the issue of parent abuse and the challenges which it poses to current understandings of domestic violence. It then specifically considers the issue of problematic 'cycle of violence' theories in the context of parent abuse. The article then explores how the developing issue of parent abuse may pose considerable issues in relation to the construction of teenage boys, masculinity and violence. The article concludes with some reflections on possible future directions for research into parent abuse in relation to masculinity, and the significance of this for teenage boys.

\section{Situating parent abuse as a domestic violence problem}

Since the 1970s, the 'hidden' problem of male violence against women has been made more visible by feminists and has provided the impetus for the construction of a legal and policy framework which aims to respond to the perpetration of such violence (Dobash and Dobash, 1979, 1992). ${ }^{2}$ Feminists have persuasively argued that male violence towards women is part of a 'constellation of abuse' by which men exert power and control over women in society (Dobash and Dobash, 2004: 328). Indeed, many feminists have come to believe that male violence against women is a form of 'patriarchal terrorism' which is: 'a product of patriarchal traditions of men's right to control "their women" ... that 
involves the systematic use of not only violence, but economic subordination, threats, isolation and other control tactics' (Johnson, 1995: 284).

Significantly, feminists have deepened understandings of why such violence is hidden through highlighting the different forms this abuse can take, such as sexual violence, (Kelly, 1988) and, more recently, through the experiences of children and the effects which violence may have upon them (Mullender and Morley, 1994; McGee, 2000; Mullender et al., 2002; Hester et al., 2007). The insights which feminists have shared by focusing attention on the male perpetrators themselves (for examples see Hearn, 1998; Dobash et al., 2000) have also been vital in drawing blame away from women for being victims, and in questioning negative female stereotypes. Alongside these developments, feminists have explored the differences and similarities between men's violence to women, women's violence to men (Dobash and Dobash, 2004), violence in gay and lesbian relationships (Herek and Berrill, 1992) and ethnic and class differences in experiences between women who experience male violence (Mullender and Morley, 1994; Patel, 2000). Undoubtedly, these insights have been vital in understanding the problem of male violence against women in society.

While the feminist paradigm of violence as involving a female adult and/or child victim and a male adult aggressor still remains dominant (Grady, 2002: 80), there is increasing recognition of the limitations of such an approach. Parent abuse, in particular, presents new complexities which impact on understandings of violence, specifically in relation to 'cycle of violence' theories. This does not mean, however, that there are not significant commonalities between 'traditionally conceived' domestic violence and parent abuse. Thus, it is well established that rates of reporting for all kinds of domestic violence are unusually low and it is underreported as a phenomenon, particularly in relation to sexual violence and female to male violence (Kelly, 1988; Grady, 2002). Similarly, it is likely that parent abuse remains underreported, even with an 11 per cent incidence rate typically cited (Crichton-Hill et al., 2006), although caution needs to be taken as estimates from existing studies may overestimate its incidence due to the emphasis on vulnerable families.

Indeed, it has been recently commented that there has been a silence surrounding the issue of parent abuse (Hunter et al., 2010), which may be reflected in a lack of reporting, at least at the official state level. ${ }^{3}$ A similar underreporting is demonstrated by research into violence within adult intimate relationships. The impact of the many forms that such violence can take, such as emotional, sexual, physical, financial and psychological abuse (Home Office Circular 19/2000 quoted in Walklate, 2004: 127) for example, has meant that for many women 'a sense of shame and responsibility, along with fear of reprisals, keeps them silent, sometimes for years' (Dobash and Dobash, 1992: 4). This shame is often felt by victims for 'allowing' the violence to happen to them (Stanko, 1985: 2). Thus, the violence is often never reported by women because it is often seen as an indication of a personal failure as a partner and as a mother, which is reinforced by the perpetrator's constant attack on the woman's positive sense of herself (Stanko, 1985: 55).

Likewise, our knowledge of the occurrence and nature of the phenomenon of parent abuse is likely to be fraught with similar issues of underreporting which violence against women has historically suffered from. These include the fear of reprisals from the perpetrator and the shame and stigma of experiencing violence from your own children, which can raise doubts as to the victim's own skills as a 'good parent'. Hunter et al.'s study found that: 
$[T]$ he stigma and shame, often combined with a sense of self-blame mothers felt for 'failing' to stop the violence. As a consequence many mothers talked about their reluctance to tell anyone what had happened. (2010: 270)

Other commentators have reported similar findings. As Cottrell states:

They [parents] feel hopeless, helpless and in emotional turmoil because they are unable to control the situation and because of the possible physical danger. These are parents who have lost their leadership role in their families and are shocked that this could happen. (Cottrell, 2004: 57)

This evidence suggests that the shame and secrecy which surrounds violence against women due to fear of reprisals may be replicated in relation to parents experiencing abuse from their children.

Significantly, similarly to the experience of women who experience male adult violence, mothers who experience parent abuse feel at fault for their children's violence because they have 'allowed' them to be exposed to the adult violence they suffered (Cottrell, 2004: 50-1). This sense of self-blame may be magnified by the emphasis on parents, particularly mothers, to maintain (adult) control of their children (Hendrick, 1997) or face punitive legal sanctions such as Parenting Orders (Holt, 2008). There is also evidence that due to the gendered nature of domestic violence and women's caring responsibilities towards children, mothers are more likely to experience parent abuse (Cottrell, 2001: 45; Hunter et al., 2010). The 'fact' that mothers are the main victims of parent abuse should be questioned because of evidence that fathers are also abused, but that it is underreported due to them feeling ashamed of a perceived loss of masculinity (SAAIF, 2010).

The focus upon mothers as victims can also lead to 'mother blaming'. Lack of appropriate parenting skills are often cited in parent abuse studies as a 'reason' for the abuse occurring, thus positioning mothers as 'failing parents' (Cottrell, 2001; Baker, 2009: 445). In the context of domestic violence, similar discourses have blamed mothers (Baker, 2009: 445). There is, therefore, a danger of the re-emergence of mother-blaming in the context of parent abuse, which lacks an understanding of the complexity of family relationships and caring responsibilities.

The following section of this article will discuss and problematise 'cycle of violence' theories which have historically been applied to adult domestic violence, in relation to their possible re-emergence in the context of the search for explanations as to why child to parent violence occurs.

\section{Problematising 'cycle of violence' theories in the context of parent abuse}

The constraints of the dominant feminist paradigm of violence can be demonstrated through historical and current domestic violence research which often links aggression in teenage boys who have experienced domestic violence with the behaviour of the perpetrator, usually male, simply because they are of the same gender (Baker, 2009). Such assumptions draw on 'cycle of violence' or 'intergenerational transmission of violence' theories (Hester et al., 2007: 72-4), which originally gained prominence during the 1970s in the USA and gained some influence in the UK in the 1980s (Wilcox, 2012, this 
volume). ${ }^{4}$ These theories presume stereotypical gendered effects upon girls and boys who experience domestic violence, such that girls will react in passive, submissive and internalised ways in response to the violence such as anxiety and depression, whereas boys will 'act out' and be violent and express their distress in externalised ways (Hester et al., 2007: 72).

Significantly, cycle of violence theories have also been used in order to try to further understanding of the impact on teenagers of experiencing violence (McGee, 1997: 19). This explanation has grown from overly deterministic social learning theories, which attribute the way a person behaves to the behaviour they have seen in their adult role models. Such theories are problematic for teenage boys because they presume that all men have a propensity to commit violence simply because they are male, and that all men unproblematically subscribe to what commentators have termed a 'hegemonic (version of) masculinity' (Connell, 1995: 77; Newburn and Stanko, 1995: 4; Collier, 1998). Moreover, 'cycle of violence' theories are problematic because they assume certain impacts of male family role models upon teenage boys (Ruxton, 2009: 69).

Thus, and most significantly, deterministic 'cycle of violence' theories perceive children without agency to choose how they feel and react to the violence they have experienced in the past. In so doing, they construct children as mere receptacles for adult behaviour, which has been demonstrated to be an outdated and overly simplistic view of childhood (James et al., 1998: 9-21). Consequently, these 'cycle of violence' theories have been widely discredited (Kelly, 1994; Mullender et al., 2002,) because they make generalisations about the futures of all children who experience violence, thereby treating them as an homogenous (socially constructed) group, rather than as distinct individuals whom experience violence and react to it differently (Mullender et al., 2002: 114) and who are active agents in the construction of their own lives (James and Prout, 1990: 4; James et al., 1998: 182).

Thus, there is not a simplistic gendered script for how children react to experiencing violence directed at their parents (Mullender et al., 2002: 114). Hester et al.'s study, for example, found that there are many factors including gender, which influence how children respond to the violence they experience, which may, but not necessarily, include exhibiting violent behaviour as a strategy to protect themselves from further violence (2007). Significantly, Mullender et al.'s study also discovered 'sensitive and thoughtful boys who were concerned for the well-being of their mother and siblings' (2002: 113). These findings suggest that there are complex reasons as to how and why children experience and react to experiencing violence, which are not solely based upon presumed gender norms.

Although 'cycle of violence' theories have been widely discredited as being overly simplistic, deterministic and reductionist ${ }^{5}$ in relation to the meaning and experience of domestic violence in children's lives (see for example Kelly, 1994; Mullender et al., 2002), there is research evidence that some domestic violence service providers continue to believe in them (Stalford et al., 2003; Baker, 2009). ${ }^{6}$ Why these discredited theories continue to exert some influence can be explained by Kelly. She states:

It has common sense appeal. But most importantly, it excludes more challenging explanations those which question power relations between men and women, adults and children. Breaking 
cycles is much easier and safer to discuss than changing the structure of social relations. (1994: 51)

Arguably the underlying factor which gives such 'common sense' understandings power is their adherence to assumed gender norms and their effects (Phillips and Phillips, 2010: 297), which problematically position men as violent by 'nature' and potentially violent (Baker, 2009), and women as 'naturally' caring and therefore passive victims. Such approaches fail to question the construction of gender in society and why some individuals choose to take up certain subject positions and others do not (Hearn, 1996). The application of these theories to teenagers specifically may also be explained by the relative lack of research conducted in relation to them (Baker, 2005). The paucity of information about teenagers who stay in refuges in comparison to younger children has meant that research studies often neglect this population (Hague et al., 1994). Therefore, 'cycle of violence' theories may be an attractive common sense explanation for elucidating the experiences of teenagers in the absence of other explanations.

More specifically, in relation to child to parent violence there is a danger that such theories may re-assert themselves in this context as a viable explanation for why children and young people might abuse their parents. There is also a danger that the considerable strides which researchers have historically made to explain and explore the complex phenomenon of domestic violence will once more be overly simplified according to gender stereotypes.

The following section of this article will now turn to explore the complexities raised by parent abuse, specifically in relation to teenage boys and the construction of masculinity and violence.

\section{Constructing masculinity and violence in relation to parent abuse}

Some research evidence suggests that the main perpetrators of parent abuse are young teenage males (Nixon et al., 2010). This evidence, however, is contested with other studies, suggesting that the differences between incidence rates amongst female and male teenage perpetrators are minimal (see Beihal in this edition; Cottrell, 2004: 72-3). Cottrell for example, states:

I suspect that boys continue to be more violent than girls, but girls are more violent than they have been in the past. We do know that the majority of violent crimes are committed by men and that men are socialized to be more aggressive, dominant and competitive than women (2004: 73).

The assumption that it is teenage boys who mainly perpetrate parent abuse is, as Cottrell states, without definitive evidence. As discussed earlier in this article, this assertion is based upon a highly problematic assumed trajectory that young teenage males who witness and experience familial domestic violence are likely to be violent; that is, there is a 'cycle of violence' whereby boys grow up to be perpetrators of violence and girls grow up to be passive victims of violence (Hester et al., 2007: 72-3). It is a perception largely based upon the ways in which men and boys are thought to be socialised to 'naturally' be more violent than girls, despite research which evidences teenage girls also as perpetrators of parent abuse (Cottrell, 2004; SAAIF, 2010). 
Such theories therefore are arguably based upon a highly contested dominant or hegemonic conception of masculinity which does not fit the majority of men and correlates masculinity, violence and men together in an overly simplistic manner (Connell, 1995: 77, Newburn and Stanko, 1995: 4; Collier, 1998). New theorising is needed in relation to how masculinity is constructed in the context of all forms of domestic violence (Baker, 2009: 444), but specifically in relation to parent abuse. Such theorising is needed to investigate and explore how teenage boys are constructed as 'potentially violent men' in relation to both masculinity and violence, and why the complexities of how gender is constructed in this regard have a tendency to be oversimplified and presented in a deterministic manner.

Moreover, such assumptions can unfairly label all young teenage males as 'potentially violent men', simply because they happen to be of the same gender as the traditional perpetrator of domestic violence (Baker, 2005, 2009). As Kelly states:

For example, some boys - we don't know what proportion or what accounts for this response identify strongly with their mothers, and distance themselves from aggressive masculinity. Some girls are judgemental and blaming of their mothers, and try to distance themselves from traditional femininity (1994: 49).

Thus, it is overly simplistic to say that experiencing domestic violence or abuse causes a child or young person to behave in ways which lead to abuse against their parent, who is usually the mother (Hester et al., 2007: 72-3). This also ignores the agency that individual children and young people have, to be actively involved in the construction of their own lives in non-violent ways (James and Prout, 1990: 4).

Experiencing domestic violence as a child is however, a risk factor for parent abuse but 'less than $50 \%$ of such boys (probably much less than $50 \%$ ), and far fewer girls, go on to abuse their mothers' (Gallagher, 2004b: 97). It is therefore not accurate to assume that the majority of children who experience domestic violence will go on to perpetrate parent abuse. As Gallagher states:

[T] he idea that any behaviour is inevitable, uncontrollable or excusable by gender, diagnosis or past experience is simplistic, discriminatory and unhelpful. (2004b: 98)

Current research in relation to parent abuse is arguably based upon presumptions of hegemonic masculinity which cannot function without a dominant version of conventional or appropriate femininity; the process by which women are gendered and become specific types of women (Skeggs, 1997: 99). Conventional or appropriate femininity plays a significant role in how women and young girls are constructed in relation to violence as certain attitudes, characteristics, behaviours and experiences such as passivity and weakness, are constructed as 'feminine', whilst others are not (Schneider, 2000: 84). There is evidence that parents, particularly victims who are fathers, are reluctant to report abuse from girls for fear of being seen unmanly, or for mothers as a result of fear of being perceived as a 'faulty' or an inappropriate female role model (SAAIF, 2010). It is clear therefore that a re-thinking of essentialist models of gender which 'undifferentially present women as victims and men as oppressors' (Newburn and Stanko, 1994: 165) is needed in relation to parent abuse. 
Consequently, the question must be asked as to whether it is useful to discuss masculinity in relation to any form of violence, including parent abuse (Hearn, 1996). Significantly, there are limitations of linking theories of masculinity based upon deterministic sex role theory, such as 'cycle of violence' theories discussed earlier, which suggest that all teenage boys will replicate the behaviour of the adult perpetrator. This is because, according to Hearn, theories which are based upon sex roles neglect the analysis of power. Thus, he states 'masculinities are no longer individual possessions, but are institutional practices located in structures of power' (Hearn, 1996: 206). By this he means that masculinities as gender are subject to changing cultural and social definitions. Thus, at any given moment, the question which needs to be asked is why do such ideas around masculinities gain prominence and thus power, and what is the process by which certain behaviours or traits are 'coded' or inscribed as masculine (Collier, 1998: ix).

Furthermore, Edley and Wetherell argue that the association of men and manliness with certain traits, such as physical strength and rigorous ability, is a late twentieth century cultural construction, not a 'natural' given for masculinity nor men, which has allowed men to maintain their dominance in society over women through the construction of what it means to be a man or woman and what constitutes man's or women's work (1996: 106-7). Far from suggesting active male conspiracies, it is significant because men have power over women: 'because they have managed to gain a stranglehold on meaning' (1996: 107). Thus, men are able to maintain their power and neutralise its appearance as power, because men, masculinity and certain traits are constructed as 'natural', which appear to be 'just the way it is' (Edley and Wetherell, 1996: 108). This explanation is supported by Kelly's argument, that:

'cycle of violence' theories, which are particularly applied in relation to teenage boys, are able to maintain their power precisely because they have common sense appeal and avoid seeking more challenging explanations - those which question power relations between men and women, adults and children. (Kelly, 1994: 51)

Exploring the presumed 'natural' link between boys, men and violence means questioning the 'naturalness' of men as the stronger sex with the potential to be violent, and alongside it, other presumptions which construct what it means to be a man. Thus it questions how power is held by men in society through meaning. When discussing teenage boys as potentially violent men, the question needs to be asked as to why it is common sense to align boys with violent behaviour and what purposes of power does this serve in relation to what it means to be a man in society. Connell for example, argues that there are benefits for men from the gendered division of labour (2000: 24).

Furthermore, more complex theorisation is needed to explain why some men choose to hold certain subject positions in relation to masculinity and violence and others do not (Connell, 2000: 20). In relation to teenage boys in particular, we need to ask why some boys (the overwhelming majority) choose not to follow the adult perpetrator's behaviour. One suggestion is that the decision as to whether we choose to invest in or identify with one discursive position rather than another relates to gaining 'enough power in relation to the other to protect their vulnerable selves' (Jefferson, 1994: 27). Thus it could be argued that therapeutic work with children who experience violence is critical in order to empower and define them(selves) by more than their experiences of violence and presumed gender roles (Phillips and Phillips, 2010). 
Significantly, Hearn asks whether masculinity as a concept relates to the male gender or sex at all as it constantly shifts during the lifetime of a man (Hearn, 1996: 210). The multiple uses and meanings, to which masculinity is now put, such as listing traits, make it a less precise concept by which to investigate the relationship between men and violence. Furthermore, masculinity is not necessarily just about or relating to men (Connell, 2000: 17) and masculinity and femininity are also configurations of gender practice which are not determined by male bodies (Connell, 2000: 29). The categories of masculinity and femininity are also not neutral and are based upon heterosexual dimorphism (Hearn, 1996: 212). They are also invested in relation to class, race and ethnicity in addition to issues of power (Connell, 2000: 34). Thus, when discussing teenage boys who do or do not abuse their parents, it is wise to consider the insights of feminists who argue that all these factors are critical to a full understanding of the complexities involved when children experience and react to domestic violence (McGee, 2000; Mullender et al., 2002; Hester et al., 2007), rather than resorting to deterministic gendered explanations.

\section{Conclusion}

It remains clear that parent abuse poses conceptual but not insurmountable challenges for the dominant feminist paradigm and understanding of domestic violence. Moreover, there are significant insights into parent abuse, understood as part of the wider phenomenon of domestic violence, which have been gained from an understanding of adult violence. These include for example, the secrecy and shame which is an integral part of the experience of such violence which is a key reason why it is underreported as a crime. Parent abuse however, requires a specific conceptual framework of its own, similar to those conceived for other forms of violence such as child or elder abuse. This framework would provide an understanding of the commonalities of parent abuse with adult domestic violence, but also its differences from it, which include complexities such the power relations between adults and children which are implicit in such violence.

This requires and challenges us to provide complex rather than simple explanations for parent abuse, which includes a refusal to defer to 'common sense' problematic 'cycle of violence' theories in an attempt to gain answers, which can unfairly stigmatise teenage boys in particular, and ignores the diversity of how individual children experience and react to violence.

Consequently, it is vital that the concept of masculinity is further explored in this context as a social construct which 'creates' gender roles and 'common sense' understandings of what it is to be a man or woman in society, and how this may be expressed through masculinity. Above all, the role of (male) power which is naturalised in the construction of masculinity, men and violence needs to be questioned in relation as to why some men take up these subject positions whilst others resist.

Lastly, it is vital that research is conducted involving and with children, particularly teenage boys, in order that they are not unfairly labelled or stigmatised as 'potentially violent men' and that they, like all children who experience violence, are understood as active agents in the construction of their own lives with the ability to choose what kind of a man or woman, violent or not, they want to be. 


\section{Acknowledgments}

The author would like to thank the anonymous reviewers for their helpful comments on an earlier version of this article, her good friends and her colleagues (past and present) for their support and encouragement in writing this article.

\section{Notes}

1 See Nixon et al. (2010) for an exception to this, and cf. to studies in Australia by Gallagher (2004a, b) and in Canada by Cottrell (2004).

2 See Wilcox (2012), this volume for a more detailed explanation of these developments; see also Dobash and Dobash (1992)

3 There is evidence amongst practicioners that parent abuse is not an uncommon experience for many families, see for example the TULIP project, Liverpool. A service which was ironically cut because of over demand from families for help with parent abuse (Purdy, 15th March 2003).

4 Also see Wilcox (2012), this volume for further exploration of the history of this issue.

5 This will be explored in the final section of the article.

6 See also a recent study in 2010 (Phillips and Phillips, 2010: 297).

\section{References}

Baker, H. (2005) 'Involving children and young people in research on domestic violence and housing', Journal of social Welfare and Family Law, 27, 3-4, 281-98.

Baker, H. (2009) "'Potentially violent men?": teenage boys, access to refuges and constructions of men, masculinity and violence', Journal of Social Welfare and Family Law, 31, 4, 435-50.

Collier, R. (1998) Masculinities, Crime and Criminology: Men, Heterosexuality and the Criminal(ised) other, London: Sage.

Connell, R. W. (1995) Masculinities, Cambridge: Polity Press.

Connell, R. W. (2000) The Men and the Boys, Oxford: Polity Press.

Cottrell, B. (2001) Parent Abuse: The Abuse of Parents by their Teenage Children, Ottowa: Family Violence Prevention Unit, Health Canada.

Cottrell, B. (2004) When Teens Abuse their Parents, Nova Scotia: Fernwood Publishing.

Crichton-Hill, Y., Evans, N. and Meadows, L. (2006) 'Adolescent violence towards parents', Te Awatea Review, 4, 2, 21-2.

Dobash, R. E. and Dobash, R. P. (1979) Violence against Wives: A Case against the Patriarchy, London: Open Books.

Dobash, R. E. and Dobash, R. P. (1992) Women, Violence and Social Change, London: Routledge.

Dobash, R E., Dobash, R. P., Lewis, R. and Cavanagh, K. (2000) Changing Violent Men, London and Thousand Oaks: Sage.

Dobash, R. P. and Dobash, R. E. (2004) 'Women's violence to men in intimate relationships: working on a puzzle', British Journal of Criminology, 44, 3, 324-49.

Edley, N. and Wetherell, M. (1996) 'Masculinity, power and identity', in M. Mac an Ghaill (ed.), Understanding Masculinities, Buckingham: Open University Press, pp. 97-113.

Gallagher, E. (2004a) 'Parents victimised by their children', Australian and New Zealand Journal of Family Therapy, 25, 1, 1-12.

Gallagher, E. (2004b) 'Youth who victimise their parents', Australian and New Zealand Journal of Family Therapy, 25, 2, 94-105.

Grady, A. (2002) 'Female-on-male violence', in C. Hoyle and R. Young (eds.), New Visions of Crime Victims, Oxford: Hart Publishing.

Hague, G., Kelly, L., Malos, E., Mullender, A. and Debbonaire, T. (1994) Children, Domestic Violence and Refuges: A Study of Needs and Responses, Bristol: WAFE.

\section{CAMBRIDGE JDURNALS}


Hearn, J. (1996) 'Is masculinity dead? A critique of the concept of masculinity/masculinities', in M. Mac an Ghaill (ed.), Understanding Masculinities, Buckingham: Open University Press, pp. 202-17.

Hearn, J. (1998) The Violences of Men, London: Sage Publications.

Hendrick, H. (1997) 'Constructions and reconstructions of British childhood: an interpretative study, 1800 to the present', in A. James and A. Prout (eds.), Constructing and Reconstructing Childhood, London: Falmer Press, pp. 34-62.

Herek, G. M. and Berrill, K. T. (eds.) (1992) Hate Crimes: Confronting the Violence against Lesbians and Gay Men, London: Sage Publications.

Hester, M., Pearson, C. and Harwin, N., with Abrahams, H. (2007) Making an Impact: Children and Domestic Violence - A Reader, London: Jessica Kingsley.

Holt, A. (2008) 'Room for resistance? Parenting orders, disciplinary power and the production of "the bad parent"', in P. Squires (ed.), ASBO Nation: The Criminalisation of Nuisance, Bristol: The Policy Press, pp. 202-22.

Hunter, C., Nixon, J. and Parr, S. (2010) 'Mother abuse: a matter of youth justice, child welfare or domestic violence', Journal of Law and Society, 37, 2, 264-84.

James, A., Jenks, C. and Prout, A. (1989) Theorizing Childhood, Cambridge: Polity Press.

James, A. and Prout, A. (1990) Constructing and Reconstructing Childhood: Contemporary Issues in the Sociological Study of Childhood, London: The Falmer Press.

Jefferson, T. (1994) 'Theorising masculine subjectivity', in T. Newburn and B. Stanko, Just Boys Doing Business: Men, Masculinities and Crime, London and New York: Routledge, pp. 10-31.

Johnson, M. P. (1995) 'Patriarchal terrorism and common couple violence: two forms of violence against women', Journal of Marriage and Family, 57, 2, 282-94.

Kelly, L. (1994) 'The interconnectedness of domestic violence and child abuse: challenges for research, policy and practice', in A. Mullender and R. Morley (eds.), Children Living with Domestic Violence, London: Whiting \& Birch, pp. 43-56.

Kelly, L. (1988) Surviving Sexual Violence, Cambridge: Polity Press.

McGee, C. (1997) 'Children's experiences of domestic violence', Child and Family Social Work, 2, 13-23.

McGee, C. (2000) Childhood Experiences of Domestic Violence, London: Jessica Kingsley.

Mullender, A., Hague, G., Imam, U., Kelly, L., Malos, E. and Regan, L. (2002) Children's Perspectives on Domestic Violence, London: Sage Publications.

Mullender, A. and Morley, R. (eds.) (1994) Children Living with Domestic Violence, London: Whiting \& Birch.

Newburn, T. and Stanko, E. A. (1995) 'When men are victims: the failure of victimology', in T. Newburn and E. A. Stanko (eds.), Men, Masculinities and Crime: Just Boys Doing Business?, London: Routledge, pp. 153-65.

Nixon, J., Hunter, C. and Parr, S. (2010) 'Mother abuse: a matter of youth justice, child welfare or domestic violence?', Journal of Law and Society, 37, 2, 264-84.

Patel, P. (2000) 'Southall black sisters: domestic violence campaigns and alliances across the divisions of race, gender and class', in J. Hanmer and C. Itzin, with S. Quaid and D. Wigglesworth, Home Truths about Domestic Violence: Feminists Influences on Policy and Practice, A Reader, London and New York: Routledge, pp. 24-43.

Phillips, B. and Phillips, D. A. (2010) 'Learning from youth exposed to domestic violence: decentering DV and the primacy of gender stereotypes', Violence Against Women, 16, 3, 291-312.

Purdy, C. (2003) 'Parents face their violent children', BBC Online, http://news.bbc.co.uk/1/hi/england/ 2824537.stm [accessed 19.07.2011].

Ruxton, S. (2009) Man Made: Men, Masculinities and Equality in Public Policy, London: Coalition of Men and Boys.

Schneider, E. (2000) Battered Women and Feminist Lawmaking, New Haven: Yale University Press.

Skeggs, B. (1997) Formations of Class and Gender, London: Routledge.

Stalford, H., Baker, H. and Beveridge, F. (2003) Children and Domestic Violence in Rural Areas: A ChildFocused Assessment of Service Provision, Plymbridge: Save the Children Fund.

\section{CAMBrIDgE JUURNALS}


Stanko, E. (1985) Intimate Intrusions: Women's Experiences of Male Violence, London: Routledge.

Stopping Aggression and Anti Social Behaviour (SAAIF) (2010) SAAIF Project, Presentation given at RESPECT Conference, 6 October, Coventry.

Ulman, A. and Strauss, M. A. (2000) 'Violence by children against mothers in relation to violence between parents and corporal punishment by parents', Journal of Comparative Family Studies, 34, 41-60.

Walklate, S. (2004) Gender, Crime and Justice, Devon: Willan Publishing.

Wilcox, P. (2012) 'Is parent abuse a form of domestic violence?', Journal of Social Policy and Society, 11, 2 , this volume.

\section{CAMBRIDGE JDURNALS}

